\begin{tabular}{|c|c|c|c|}
\hline \multirow{3}{*}{$\begin{array}{r}\text { Case Reports in } \\
\text { Gastroenterology }\end{array}$} & \multirow{2}{*}{\multicolumn{2}{|c|}{ Case Rep Gastroenterol 2017;11:54-58 }} & \multirow[b]{3}{*}{ Oparger } \\
\hline & & & \\
\hline & $\begin{array}{l}\text { DOI: 10.1159/000456604 } \\
\text { Publisned online: January 31, } 2017\end{array}$ & $\begin{array}{l}\text { (c) } 2017 \text { The Author(s)Published by S. } \\
\text { Karger AG, Basel } \\
\text { www.karger.com/crg }\end{array}$ & \\
\hline & $\begin{array}{l}\text { This article is licensed under the } \\
\text { International License (CC BY-NC) } \\
\text { Usage and distribution for commerc }\end{array}$ & $\begin{array}{l}\text { mons Attribution-NonCommercial } 4.0 \\
\text { rger.com/Services/OpenAccessLicense). } \\
\text { quires written permission. }\end{array}$ & \\
\hline
\end{tabular}

\title{
Spontaneous Splenic Infarcts in a Cirrhotic Patient with Primary Biliary Cirrhosis
}

\author{
Fredy Nehme Kyle Rowe Ahmad Haris Imad Nassif \\ Department of Internal Medicine, Kansas University School of Medicine, Wichita, KS, USA
}

\section{Keywords}

Spontaneous splenic infarction $\cdot$ Primary biliary cirrhosis $\cdot$ Portal hypertension

\begin{abstract}
Spontaneous splenic infarction has been rarely reported as a complication of cirrhosis and portal hypertension. We describe the case of a 67-year-old female with past medical history of primary biliary cirrhosis presenting for a 1-day history of left upper quadrant pain. Investigations were in favor of splenic infarcts secondary to portal hypertension. The patient improved with conservative management and no recurrence was noted on further follow-up. Splenic infarction must be kept in mind when a patient with cirrhosis presents with left upper quadrant abdominal pain without a clear source.

(C) 2017 The Author(s) Published by S. Karger AG, Basel
\end{abstract}

\section{Introduction}

Splenic infarction is an uncommon medical condition most commonly associated with a hypercoagulable state or a cardiovascular etiology. Presentation is variable and can mimic other causes of acute abdominal pain [1]. The typical presentation includes a left upper quadrant abdominal pain radiating to the left shoulder [2]. Diagnosis is usually based on clinical findings and splenic imaging. Most cases result in focal infarction and treatment is mainly conservative. The association with cirrhosis is rare and only a few cases have been 


\section{Case Reports in Gastroenterology}

Case Rep Gastroenterol 2017;11:54-58 DOI: $10.1159 / 000456604$

(c) 2017 The Author(s). Published by S. Karger AG, Basel www.karger.com/crg

Nehme et al:: Spontaneous Splenic Infarcts in a Cirrhotic Patient with Primary Biliary Cirrhosis

reported to date. We describe the case of an elderly female patient with known history of primary biliary cirrhosis presenting for left upper quadrant abdominal pain secondary to splenic infarction.

\section{Case Report}

A 67-year-old female presented for a 1-day history of left upper quadrant abdominal pain. She described the pain as moderate, sharp, and radiating to her left shoulder. There was no history of fever, chills, abnormal bowel movements, nausea, or vomiting. Her past medical history was remarkable for cirrhosis secondary to primary biliary cirrhosis complicated by hepatic encephalopathy and ascites. She denied recent trauma, previous miscarriage, deep vein thrombosis, or embolic disease. Medications included furosemide, spironolactone, rifaximin, lactulose, ursodiol, and lansoprazole. She had no known allergies. Physical examination was normal apart from epigastric and left upper quadrant tenderness. No ascites was noted. Laboratory results on admission were comparable to previous routine blood draws done 2 months earlier and were the following: hemoglobin $10.3 \mathrm{~g} / \mathrm{dL}$, hematocrit $32 \%$, platelet count $55 \times 10^{3} / \mu \mathrm{L}$, white blood cell count $9.1 \times 10^{3} / \mu \mathrm{L}$, international normalized ratio 1.5, aspartate aminotransferase $39 \mathrm{IU} / \mathrm{L}$, alanine aminotransferase $35 \mathrm{IU} / \mathrm{L}$, alkaline phosphatase $151 \mathrm{IU} / \mathrm{L}$, total bilirubin $2 \mathrm{mg} / \mathrm{dL}$, total protein $5.6 \mathrm{~g} / \mathrm{dL}$, and albumin 2.3 $\mathrm{g} / \mathrm{dL}$. EKG, chest X-ray, and cardiac enzymes were all within normal range.

Computed tomography (CT) scan of the abdomen with contrast revealed cirrhotic morphology of the liver, large varices in the right lower quadrant, and numerous wedge-shaped areas of hypoenhancement extending to the periphery of the spleen concerning for splenic infarcts (Fig. 1).

Doppler ultrasound of the spleen confirmed the presence of infarcts with preserved flow within the main splenic artery. Further evaluations were performed to rule out other secondary causes of spontaneous splenic infarcts including a hypercoagulable workup, autoimmune disease markers, and an echocardiogram. All were unremarkable.

The patient was treated with conservative management and analgesia. She reported progressive improvement over the next few weeks. Follow-up at 2 months showed consistent resolution of her clinical symptoms and signs. A repeat CT scan of the abdomen showed stable splenic infarcts.

\section{Discussion}

Splenic infarction is an uncommon cause of abdominal pain that usually occurs as a result of occluded splenic artery or one of its branches with a clot or an infected embolus. Most common symptoms include left-sided abdominal pain, fever, nausea, and vomiting. In many cases, splenic infarction can be the primary presentation of an underlying condition [1].

In about two-thirds of the cases, splenic infarction is reported as a result of a hypercoagulable state including hematologic malignancies or a cardiovascular etiology (intracardiac thrombus, bacterial endocarditis) [1]. Other less common causes include infectious mononucleosis, sickle cell disease, Gaucher disease, wandering spleen, sepsis, pancreatitis, infiltrative diseases, and collagen-vascular diseases [3]. Spontaneous splenic infarct secondary to cirrhosis and portal hypertension has been rarely described in the literature [4-8]. One large 
case series of patients with splenic infarcts reported that only 3 out of 152 patients were secondary to portal hypertension [3].

In case of underlying cirrhosis, splenic infarction has been reported after cyanoacrylate injection for gastric fundal varices [9], splenic artery ligation [10], liver transplantation [11], and histoacryl embolization [12]. Also, iatrogenic infarction may occur due to splenic artery spasm after intraarterial infusion of vasopressin for gastrointestinal bleed [13].

Spontaneous splenic infarction secondary to portal hypertension is due to hemodynamic changes rather than the occlusion of the splenic artery. The exact mechanism is unclear, although it is postulated that congestive splenomegaly resulting in greater oxygen requirements by the spleen combined with a decrease in the oxygen-carrying capacity of the blood caused by anemia results in anoxia and infarction of the spleen [4]. Also, cirrhosis often results in a hypercoagulable state [14]. The probable mechanism of splenic infarction in our patient with primary biliary cirrhosis and portal hypertension is anoxia.

Contrast CT scan is currently the best noninvasive test to diagnose splenic infarctions and to rule out other pathologies that have a similar presentation [15]. Other modalities used include ultrasound Doppler of the spleen, angiography, and scintigraphy [8]. The diagnosis of splenic infarction in our case was made by CT scan and Doppler ultrasound.

Treatment depends upon the underlying cause. In many cases, including cirrhosis, conservative management often yields good results and consists of pain control and other supportive measures. Splenectomy is only required in case of persistent symptoms or complications including splenic pseudocyst, abscess, or hemorrhage [16].

The rate of resolution of splenic infarcts is unknown; however, a few case reports documented complete resolution of infarcts due to infective endocarditis [17] and atrial fibrillation [18] on follow-up imaging. In one case with underlying cirrhosis, a defect was still present 6 months later suggesting different resolution rates depending on the underlying etiology [8].

\section{Conclusion}

Splenic infarction is a relatively uncommon cause of abdominal pain that is often overlooked. Keeping a high index of suspicion is appropriate in the presence of predisposing conditions including cirrhosis, left upper quadrant pain, and abdominal tenderness without a clear source.

\section{Statement of Ethics}

The authors have no ethical conflicts to disclose.

\section{Disclosure Statement}

The authors declare no conflict of interest. 
Nehme et al:: Spontaneous Splenic Infarcts in a Cirrhotic Patient with Primary Biliary Cirrhosis

\section{References}

1 Lawrence YR, Pokroy R, Berlowitz D, Aharoni D, Hain D, Breuer GS: Splenic infarction: an update on William Osler's observations. Isr Med Assoc J 2010;12:362-365.

2 Chin JK, McCormick PA, Hilson AJ, Burroughs AK, McIntyre N: Liver/spleen scintigraphy for diagnosis of splenic infarction in cirrhotic patients. Postgrad Med J 1993;69:715-717.

-3 Jaroch MT, Broughan TA, Hermann RE: The natural history of splenic infarction. Surgery 1986;100:743-750.

4 Matsui A, Shimada T, Sasaki N, Ishikawa T, Momoya T, Makino S: Splenic infarction in a child with portal hypertension secondary to biliary atresia. J Pediatr Surg 1997;32:648-649.

5 Capron JP, Chivrac D, Dupas JL, Rémond A, Ossart JL, Lorriaux A: Massive splenic infarction in cirrhosis: report of a case with spontaneous disappearance of hypersplenism. Gastroenterology 1976;71:308310.

-6 Yuasa K, Yamada S, Uehara M, Takehara K, Motegi K, Yamada T, et al: An autopsy case of primary biliary cirrhosis with giant splenic infarction. Nihon Shokakibyo Gakkai Zasshi 1985;82:1591-1595.

-7 Erarslan E, Bozkurt A, Yüksel I, Demır HD: Spontaneous splenic infarction in an elderly cirrhotic patient with multiple comorbidities. Turk J Gastroenterol 2012;23:596-598.

8 Chin JK, McCormick PA, Hilson AJ, Burroughs AK, McIntyre N: Liver/spleen scintigraphy for diagnosis of splenic infarction in cirrhotic patients. Postgrad Med J 1993;69:715-717. Kim J, Chun HJ, Hyun JJ, Keum B, Seo YS, Kim YS, et al: Splenic infarction after cyanoacrylate injection for fundal varices. Endoscopy 2010;42(suppl 2):E118.

10 Nordlinger BM, Fulenwider JT, Millikan WJ, Warren WD: Splenic artery ligation in distal splenorenal shunts. Am J Surg 1978;136:561-568.

-11 Dourakis SP, Alexopoulou AA, Hadziyannis SJ: Splenic infarct as a late complication of liver transplantation. Eur J Gastroenterol Hepatol 1998;10:805-808.

$\checkmark 12$ Cheng PN, Sheu BS, Chen CY, Chang TT, Lin XZ: Splenic infarction after histoacryl injection for bleeding gastric varices. Gastrointest Endosc 1998;48:426-427.

13 Sweren BS, Bohlman ME: Gastric and splenic infarction: a complication of intraarterial vasopressin infusion. Cardiovasc Intervent Radiol 1989;12:207-209.

14 Baccouche H, Labidi A, Fekih M, Mahjoub S, Kaabi H, Hmida S, et al: Haemostatic balance in cirrhosis. Blood Coagul Fibrinolysis 2016, Epub ahead of print.

-15 Antopolsky M, Hiller N, Salameh S, Goldshtein B, Stalnikowicz R: Splenic infarction: 10 years of experience. Am J Emerg Med 2009;27:262-265.

16 Hazanov N, Attali M, Somin M, Beilinson N, Goland S, Katz M, et al: Splenic embolus: 13 cases from a single medical department. Isr Med Assoc J 2006;8:694-697.

-17 Vagenakis AG, Abreau CM, Braverman LE: Splenic infarction diagnosed by photoscanning. J Nucl Med 1972;13:563-564.

18 Spencer RP: “Healing” of a splenic infarct. J Nucl Med 1974;15:303-304. 


\section{Case Reports in Gastroenterology}

www.karger.com/crg

Nehme et al.: Spontaneous Splenic Infarcts in a Cirrhotic Patient with Primary Biliary Cirrhosis

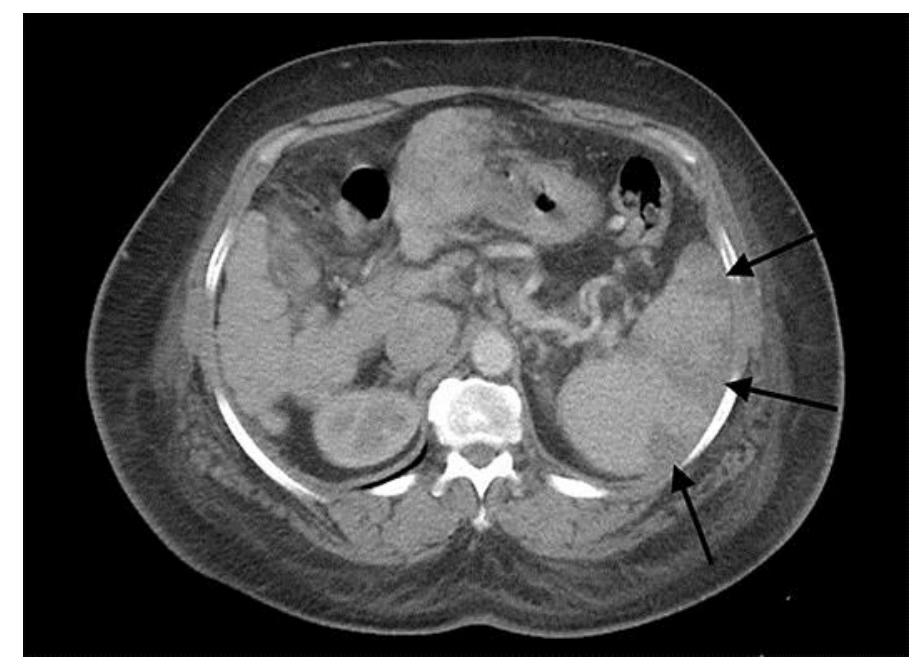

Fig. 1. Axial post-contrast-enhanced CT image showing numerous wedge-shaped areas of hypoenhancement (arrows) consistent with splenic infarcts. 